\title{
Sodium-Activated Potassium Channels Are Functionally Coupled to Persistent Sodium Currents
}

\author{
Travis A. Hage and Lawrence Salkoff \\ Department of Anatomy \& Neurobiology, Washington University School of Medicine, St. Louis, Missouri 63110
}

We report a novel coupled system of sodium-activated potassium currents $\left(I_{\mathrm{KNa}}\right)$ and persistent sodium currents $\left(I_{\mathrm{NaP}}\right)$, the components of which are widely distributed throughout the brain. Its existence and importance has not been previously recognized. Although $I_{\mathrm{KNa}}$ was known to exist in many cell types, the source of $\mathrm{Na}^{+}$which activates $I_{\mathrm{KNa}}$ remained a mystery. We now show in single membrane patches generated from the somas of rat neurons that sodium influx through $I_{\mathrm{NaP}}$ is sufficient for activation of $\mathrm{K}_{\mathrm{Na}}$ channels, without substantial contribution from the transient sodium current or bulk $\left[\mathrm{Na}^{+}\right]_{\mathrm{i}} \cdot I_{\mathrm{NaP}}$ was found to be active at cell membrane resting potentials, a finding that may explain why $I_{\mathrm{KNa}}$ can be evoked from negative holding potentials. These results show an unanticipated role for $I_{\mathrm{NaP}}$ in activating a negative feedback system countering the excitable effects $I_{\mathrm{NaP}}$; the interrelatedness of $I_{\mathrm{NaP}}$ and $I_{\mathrm{KNa}}$ suggests new ways neurons can tune their excitability.

\section{Introduction}

Sodium-activated potassium channels ( $\mathrm{K}_{\mathrm{Na}}$ channels) were first described over 25 years ago as high conductance potassium channels activated by high concentrations of internal sodium (Kameyama et al., 1984). Despite many reports of their expression throughout the nervous system and other tissues (for review, see Dryer, 1994; Bhattacharjee and Kaczmarek, 2005), it was unclear whether $\mathrm{K}_{\mathrm{Na}}$ channels were active under normal physiological conditions. Experiments with inside-out patches appeared to show that $\mathrm{K}_{\mathrm{Na}}$ channel activity requires bulk sodium concentrations in excess of that normally present in bulk cytosol. Such experiments were taken as evidence against the participation of $I_{\mathrm{KNa}}$ during normal electrophysiological activity. Rather, it was suggested that $\mathrm{K}_{\mathrm{Na}}$ channels might represent a type of "reserve conductance" active only under conditions of hypoxia when $\left[\mathrm{Na}^{+}\right]_{\mathrm{i}}$ might substantially increase. However, recent studies have shown that $\mathrm{K}_{\mathrm{Na}}$ channels produce large outward currents in several types of neurons under normal physiological conditions, and appear to be dependent on sodium influx rather than high bulk $\left[\mathrm{Na}^{+}\right]_{\mathrm{i}}$ (Budelli et al., 2009; Lu et al., 2010; Nuwer et al., 2010).

$I_{\mathrm{KNa}}$ is a tetrodotoxin (TTX)-sensitive delayed outward current that lasts for seconds but the transient sodium current $\left(I_{\mathrm{NaT}}\right)$ is over within a few milliseconds; $I_{\mathrm{NaT}}$ thus seems an unlikely

\footnotetext{
Received Oct. 7, 2011; revised Dec. 14, 2011; accepted Dec. 27, 2011

Author contributions: T.A.H. and L.B.S. designed research; T.A.H. performed research; T.A.H. analyzed data; T.A.H. and L.B.S. wrote the paper.

Support was provided by the National Institute of Neurological Disorders and Stroke Grant R01-NS0661871-01. We thank A. Butler, M. Covarrubias, and A. Wei for their helpful comments on the manuscript. We also thank the Salkoff laboratory for their assistance during the course of the study. We thank $G$. Budelli for control data from the Slack HEK cell line.

The authors declare no competing financial interests.

Correspondence should be addressed to Lawrence Salkoff, Department of Anatomy \& Neurobiology, Washington University School of Medicine, 660 S. Euclid Avenue, Box 8108, St. Louis, M0 63110. E-mail: salkoffl@pcg.wustl.edu. DOI:10.1523/JNEUROSCI.5088-11.2012

Copyright $\odot 2012$ the authors $\quad 0270-6474 / 12 / 322714-08 \$ 15.00 / 0$
}

source of $\mathrm{Na}^{+}$to activate $I_{\mathrm{KNa}}$. Here we explore the possibility that the TTX-sensitive persistent sodium current $\left(I_{\mathrm{NaP}}\right)$ is the source of $\mathrm{Na}^{+}$activating $I_{\mathrm{KNa}}$. Amplitudes of $I_{\mathrm{NaP}}$ are tiny compared with peak amplitudes of $I_{\mathrm{NaT}}$, and even prolonged $I_{\mathrm{NaP}}$ activity will not quickly increase bulk $\left[\mathrm{Na}^{+}\right]_{\mathrm{i}}$. Therefore a mechanism permitting $I_{\mathrm{NaP}}$ to deliver sufficient cytosolic $\mathrm{Na}^{+}$to activate $I_{\mathrm{KNa}}$ would require that channels underlying both currents be present together in single membrane patches. We show that the activity of $I_{\mathrm{KNa}}$ indeed depends on the activity of $I_{\mathrm{NaP}}$ by recording single-channel $I_{\mathrm{NaP}}$ and $I_{\mathrm{KNa}}$ currents in membrane patches isolated from the soma of olfactory bulb mitral cells. Single-channel currents recorded from outside-out patches revealed that treatments that eliminated $I_{\mathrm{NaP}}$, also removed $I_{\mathrm{KNa}}$; conversely, enhancing $I_{\mathrm{NaP}}$ resulted in increased $I_{\mathrm{KNa}}$ activity. This dependence of $I_{\mathrm{KNa}}$ on $I_{\mathrm{NaP}}$ was demonstrated under conditions where $I_{\mathrm{NaT}}$ was absent, and bulk $\left[\mathrm{Na}^{+}\right]_{\mathrm{i}}$ was 0 , thus verifying the importance of $I_{\mathrm{NaP}}$. These results focus further attention on $I_{\mathrm{NaP}}$ which is increasingly being recognized for its role in controlling many aspects of cell excitability (Crill, 1996; Vervaeke et al., 2006; Huang and Trussell, 2008). Although the action of $I_{\mathrm{NaP}}$ is usually thought of as producing an increase in cell excitability (Stafstrom et al., 1984) our results suggest an unanticipated role for $I_{\mathrm{NaP}}$ in activating a negative feedback system, $I_{\mathrm{KNa}}$, which provides an opposing inhibitory current.

\section{Materials and Methods}

Primary neuronal culture preparations. Primary cultures of dissociated olfactory bulbs were prepared from either sex of neonatal Sprague Dawley rats (postnatal day 0 ). Dissected olfactory bulbs were incubated in $0.25 \%$ trypsin in $\mathrm{PBS}$ for $30 \mathrm{~min}$ at $37^{\circ} \mathrm{C}$. For the last $5 \mathrm{~min}$, trypsin solution was supplemented with $0.05 \%$ DNase. Enzyme digested tissue was then triturated in PBS containing soy bean trypsin inhibitor using Pasteur pipettes of decreasing diameter. Cells were plated on poly-lysinecoated glass coverslips in Dulbecco's Modified Eagle Medium/F-12 medium (Invitrogen) with 10\% FBS and 2\% B-27 supplement (Invitrogen). Three days after plating, medium was replaced with Neurobasal (Invitrogen $)+2 \%$ B-27 supplement and $5 \mu \mathrm{M}$ arabinofuranosyl cytidine to 
a $-70 \mathrm{mV}$ holding potential
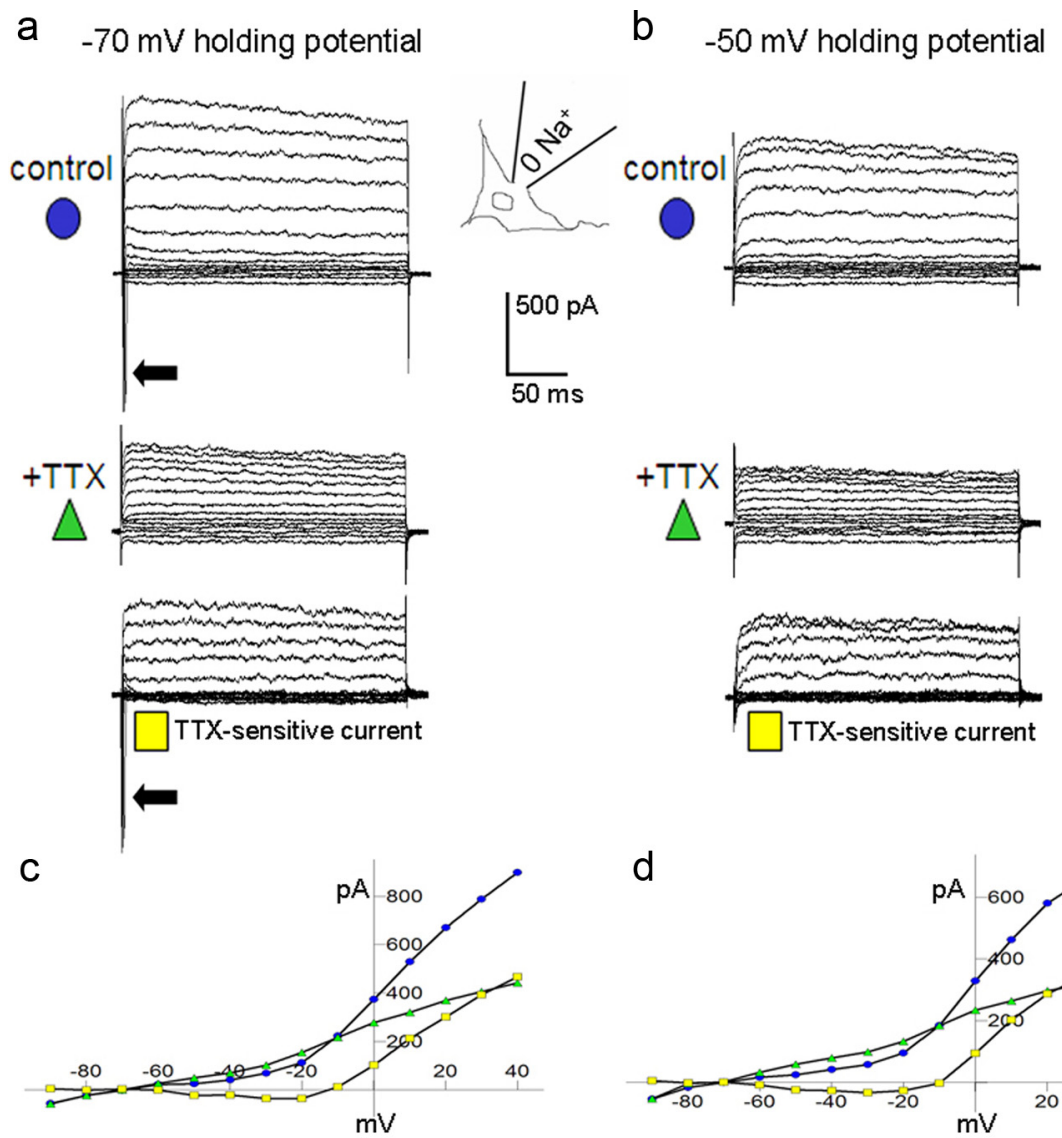

C

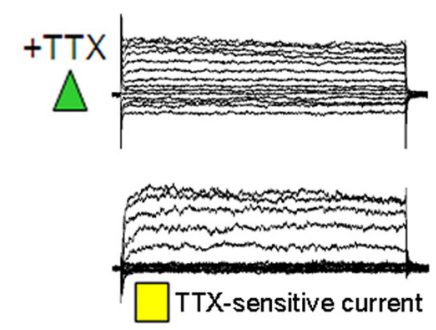

d

Figure 1. The TTX-sensitive delayed outward current, $I_{\mathrm{KNa}}$ does not depend on the transient sodium current. $\boldsymbol{a}$, Whole-cell currents before and after TTX $(1 \mu \mathrm{M})$ and TTX-sensitive currents evoked by voltage steps ( -90 to $+40 \mathrm{mV} ; 10 \mathrm{mV}$ intervals) from a holding potential of $-70 \mathrm{mV}$. Note the large component of inward $\mathrm{Na}^{+}$current present in $\boldsymbol{a}$ (arrows) but absent in $\boldsymbol{b}$. $\boldsymbol{b}$, Currents evoked from the same neuron as in $\boldsymbol{a}$ from a holding potential of $-50 \mathrm{mV}$. Note that despite the substantial diminution of the transient sodium current by holding at $-50 \mathrm{mV}$, TTX-sensitive outward currents and persistent inward currents were largely unchanged. $\boldsymbol{c}, \boldsymbol{d}, I-V$ plots of sustained currents (mean current during final $50 \mathrm{~ms}$ of voltage step) from $-70 \mathrm{mV}$ and $-50 \mathrm{mV}$ holding potentials, respectively. Recordings were made from the soma of dissociated tufted/mitral cells of the olfactory bulb.

inhibit division of glia. Whole-cell and excised patch recordings were made up to 4 and $10 \mathrm{~d}$ after plating, respectively.

Voltage-clamp recordings. Tufted/mitral cells were identified on the basis of their pyramidal shape and large size (Trombley and Westbrook, 1990). Recordings were made with borosilicate glass pipettes with tip resistances of 3-6 M $\Omega$. Outside-out patches were obtained by steadily moving the pipette away from the cell after establishing a whole-cell patch at the soma. Voltage-clamp recordings were made with an Axoclamp 200B, filtered at $2 \mathrm{kHz}$ and digitized at $50 \mathrm{kHz}$ with a Digidata 1440A. Internal pipette solution contained the following (in $\mathrm{mM}$ ): 140 $\mathrm{KCl}, 10$ HEPES, 5 EGTA, $1 \mathrm{MgCl}_{2}$, pH 7.40 with $\mathrm{KOH}$. Bath solutions contained the following (in $\mathrm{mm}$ ): $150 \mathrm{NaCl}, 10$ HEPES, 10 dextrose, 5 $\mathrm{KCl}, 2 \mathrm{MgCl}_{2}$, pH 7.30 with $\mathrm{NaOH}$. For recordings of $I_{\mathrm{Na}}$, the internal solution contained $130 \mathrm{CsCl}, 10 \mathrm{NaCl}, 1 \mathrm{MgCl} 2,10 \mathrm{HEPES}, 5 \mathrm{EGTA}, \mathrm{pH}$ 7.40 with $\mathrm{KOH}$. The external solution for recording $I_{\mathrm{Na}}$ was the same as the standard external recording solution with $10 \mathrm{~mm}$ tetraethylammonium $\left(\right.$ TEA) $\cdot \mathrm{Cl}, 2 \mathrm{~mm} 4$ aminopyridine $(4-\mathrm{AP}) \cdot \mathrm{Cl}$, and $0.2 \mathrm{mM} \mathrm{CdCl}_{2}$ replacing equimolar $\mathrm{NaCl}$. Zero $\mathrm{Na}^{+}$external solutions replaced all $\mathrm{NaCl}$ with choline $\cdot \mathrm{Cl}$ or $\mathrm{LiCl}$ as indicated. TTX and veratridine were used at 1 and $50 \mu \mathrm{M}$ concentrations, respectively. Veratridine was stored as a $50 \mathrm{~mm}$ stock frozen in DMSO. Experiments using veratridine included 0.1\% DMSO in control external solution. No effect of this concentration of DMSO on channel activity was noted. In control experiments examining the effect of TTX on Slack-transected human embryonic kidney cells, $10 \mathrm{~mm} \mathrm{NaCl}$ replaced equimolar $\mathrm{KCl}$ in the internal solution.

Single-channel analysis. Data were acquired and analyzed with pClamp 10.0 and Microsoft Excel. Single $K_{\mathrm{Na}}$ channel activity was analyzed and $\mathrm{P}_{\mathrm{o}}$ calculated using the Single Channel Search tool in pClamp 10.0. $\mathrm{K}_{\mathrm{Na}}$ channel activity was measured during repeated $3 \mathrm{~s}$ sweeps to $+60 \mathrm{mV}$ from a holding potential of $-70 \mathrm{mV}$, using a 10 s intersweep interval. Under differing experimental conditions, no changes in the mean amplitude of detected events or distribution of peaks in histograms of event amplitude were found. The number of channels in a patch was estimated by the maximum number of simultaneously active channels (additive steps) observed over the course an experiment. The minimum estimate of channel number provided by this method was used to determine $\mathrm{P}_{\mathrm{o}}$. In the majority of experiments, patches analyzed were estimated to contain $4-6$ channels. Single $I_{\mathrm{NaP}}$ channel activity was measured using Threshold Search tool in pClamp 10.0. Many of the persistent TTX-sensitive openings were so brief that we could not reliably measure a mean channel open time, even when digitizing at high rates. Thus, we used the number of detectable events, and the Threshold Search tool as a means of quantification rather than channel open probability. Threshold levels were determined by measuring unitary current levels from selected "box-like" open channel events. The brevity of many events prevented use of an all points histogram to determine unitary current level. Identical threshold searches were performed for control sweeps and sweeps evoked in TTX. A small number of events crossed threshold in TTX and those values were subtracted from corresponding control values to generate the plot in Figure $5 B$ (see Results).

Estimation of $\left[\mathrm{Na}^{+}\right]_{\mathrm{i}}$ increase. The volume of pipette solution was estimated to be $7.26 \mu$ l using the inner diameter of the recording pipettes $(0.68 \mathrm{~mm})$ and an approximation of internal solution fill height starting at the tapering of the pipette $(20 \mathrm{~mm})$. The number of $\mathrm{Na}^{+}$molecules entering the patch was estimated based on a high approximation of average $I_{\mathrm{Na}}$ throughout the experiment: -50 pA. Using the Faraday constant, this corresponds to $5.18 \times$ $10^{-16} \mathrm{~mol} / \mathrm{s}$. Given this rate of $\mathrm{Na}^{+}$influx and the volume of pipette solution, the concentration of sodium would increase by $0.257 \mu \mathrm{M}$ over the course of an hour-long experiment.

This is likely an overestimate, the fill height was usually $>20 \mathrm{~mm}$, and there is additional volume in the tapered portion of the pipette not considered here. In most excised patches, the peak amplitude of $I_{\mathrm{Na}}$ was much smaller than $-50 \mathrm{pA}$ and even smaller at the holding potential that patches were clamped at for the majority of the experiment.

Statistical analysis. We performed statistical analyses using T.W. Kirkman's Statistics to Use (http://www.physics.csbsju.edu/stats/) software. For comparison between two groups, we used paired Student's $t$ tests for the same procedures before and after applied treatments.

Animal welfare. It is the policy of Washington University Medical School that all research involving animals be conducted under humane conditions, with appropriate regard for animal welfare. Washington University Medical School is a registered research facility with the United States Department of Agriculture (USDA) and is committed to complying with the Guide for the Care and Use of Laboratory Animals (Department of Health and Human Services), the provisions of the Animal Welfare Act (USDA), and all applicable federal and state laws and regulations. At Washington University Medical School an Animal Care Committee has been established to insure compliance with all applicable federal and state regulations for the purchase, transportation, housing and research use of animals. Washington 


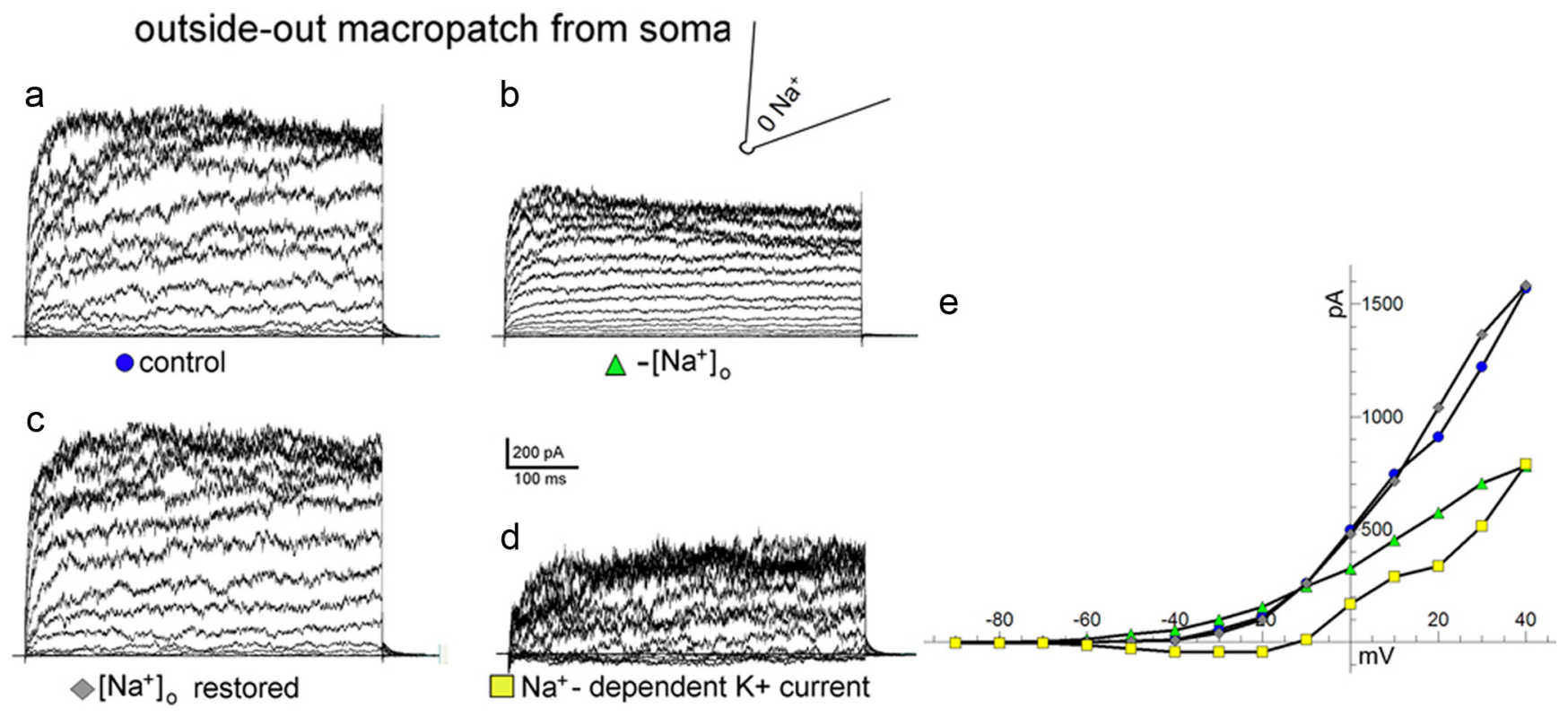

Figure 2. $I_{\mathrm{KNa}}$ depends on sodium influx into an outside-out macropatch. $\boldsymbol{a}$, Currents were evoked from a holding potential of $-70 \mathrm{mV}$ by steps from -90 to $+80 \mathrm{mV}$. $\boldsymbol{b}$, Removal of external sodium dramatically reduced magnitude of outward currents.c, Currents returned to previous levels upon restoration of external sodium.d, Delayed outward $\mathrm{Na}_{\mathrm{Na}}$ currents, revealed by subtracting $0\left[\mathrm{Na}{ }^{+}\right]_{0}$ currents from control currents, resemble those recorded in whole-cell configuration. $\boldsymbol{e}, I-V$ plot of currents in $\boldsymbol{a}-\boldsymbol{d}$ (mean current of final $50 \mathrm{~ms}$ of voltage step). Note that sodium ion was absent from the internal bulk solution.

University Medical School has filed appropriate assurance of compliance with the Office for the Protection of Research Risks of the National Institutes of Health.

\section{Results}

In whole-cell recordings of olfactory bulb tufted/mitral cells (T/M cells) (Fig. 1) or striatal medium spiny neurons (Budelli et al., 2009), blockade of voltage-gated sodium $\left(\mathrm{Na}_{\mathrm{V}}\right)$ channels with TTX $(1 \mu \mathrm{M})$ reduces the amplitude of sustained outward currents. This portion of TTX-sensitive outward current removed represents a sodiumactivated potassium current $\left(I_{\mathrm{KNa}}\right)$ (Budelli et al., 2009). As shown in Figure 1, the kinetic properties of the TTX-sensitive outward current $\left(I_{\mathrm{KNa}}\right)$ do not appear to depend on $I_{\mathrm{NaT}} ; I_{\mathrm{KNa}}$ is a long-duration delayed outward current showing very little inactivation, while $I_{\mathrm{NaT}}$ is over in a few milliseconds. Since a key feature of $I_{\mathrm{KNa}}$ is its sensitivity to TTX, an alternative to its activation by the TTX-sensitive $I_{\mathrm{NaT}}$ component could be its activation by the TTX-sensitive $I_{\mathrm{NaP}}$ which is known to accompany $I_{\mathrm{NaT}}$ in most neurons (Crill, 1996). Supporting this hypothesis are our observations showing that $I_{\mathrm{KNa}}$ persists even when $I_{\mathrm{NaT}}$ is eliminated or greatly reduced by a depolarized holding potential of $-50 \mathrm{mV}$ (Fig. $1 b$ ).

\section{$I_{\mathrm{KNa}}$ in detached outside-out patches}

Notably, the whole-cell experiments shown in Fig. 1 were undertaken with the internal bulk concentration of sodium ion reduced to virtually $0 \mathrm{mM}$. This means that the activation of $I_{\mathrm{KNa}}$ by $I_{\mathrm{NaP}}$ has to be accomplished by sodium ion crossing the membrane into the cell. This also implies that the local internal concentration of $\mathrm{Na}^{+}$in the vicinity of $I_{\mathrm{KNa}}$ must be raised to a sufficiently high level without any contribution from the bulk internal $\left[\mathrm{Na}^{+}\right]$. Because of the low conductance of $I_{\mathrm{NaP}}$ such a scenario might seem unlikely, but might be possible if channels carrying $I_{\mathrm{KNa}}$ and $I_{\mathrm{NaP}}$ were closely associated. A rigorous test of the hypothesis of the close association and functional coupling of these two channel types would be demonstrating the dependency of $I_{\mathrm{KNa}}$ on the activity of $I_{\mathrm{NaP}}$ in an isolated membrane patch.

To test this hypothesis, we recorded $I_{\mathrm{KNa}}$ currents in outsideout patches excised from the soma of T/M cells and showed their dependence on $I_{\mathrm{NaP}}$ as we had in whole-cell configuration. Figure 2 shows an outside-out macro patch containing a prominent potassium current resembling those recorded in the whole-cell configuration, but lacking any indication of $I_{\mathrm{NaT}}$ (Fig. 2a). As we showed for whole-cell currents, outward currents were substantially reduced when external sodium was removed (Fig. $2 b$ ) but returned when $\left[\mathrm{Na}^{+}\right]_{\mathrm{o}}$ was restored (Fig. 2c). In these experiments, no sodium was included in the internal pipette solution so that activation of $\mathrm{K}_{\mathrm{Na}}$ currents would be minimally dependent on bulk sodium and primarily determined by sodium influx. The component of $\mathrm{K}^{+}$current dependent on $\mathrm{Na}^{+}$influx was revealed by subtraction, and closely resembles that seen in whole-cell recordings (Fig. 2d) (amplitude of sustained outward current in external choline was reduced to $63.5 \pm 3.01 \%$ of control values $p<0.001, n=5$; upon restoration of external $\mathrm{Na}^{+}$, amplitude of sustained outward current returned to $88.4 \pm 7.39 \%$ of control values, $p<0.05$ compared with choline, mean \pm SEM, $n=5$, $\left.V_{\mathrm{m}}=+60 \mathrm{mV}\right)$. We also applied TTX to macropatches and, as in whole-cell recordings, saw a significant reduction in the amplitude of total delayed outward current, revealing a large component of $I_{\mathrm{KNa}}$ (amplitude of sustained outward current in TTX was reduced to $47.3 \pm 12.4 \%$ of control values $p<0.05$, mean \pm SEM, $\left.n=4, V_{\mathrm{m}}=+60 \mathrm{mV}\right)$. As a control for a direct effect of TTX on $\mathrm{K}_{\mathrm{Na}}$ channels, we measured whole-cell currents from a line of human embryonic kidney cells stably transfected with the Slack gene which is known to encode $\mathrm{K}_{\mathrm{Na}}$ channels, and found no change in $I_{\mathrm{KNa}}$ current amplitude following application of $1 \mu \mathrm{M}$ TTX (amplitude of sustained outward current in TTX was $101 \% \pm 2.62 \%$ of control value. $n=3$, measured at $+60 \mathrm{mV} p=$ $0.6)$. Furthermore, replacing external sodium with the $\mathrm{Na}_{\mathrm{V}^{-}}$ channel-permeant cation, lithium, also resulted in a significant decrease in the amplitude of sustained outward currents in excised patches (amplitude of sustained outward current in external $\mathrm{Li}^{+}$was reduced to $56.2 \pm 3.67 \%$ of control values $p<0.001$, $n=4$; upon restoration of external $\mathrm{Na}^{+}$, amplitude of sustained outward current returned to $78.8 \pm 3.01 \%$ of control values, $p<0.01$ compared with $\mathrm{Li}^{+}$mean $\left.\pm \mathrm{SEM}, n=4, V_{\mathrm{m}}=+60 \mathrm{mV}\right)$. 

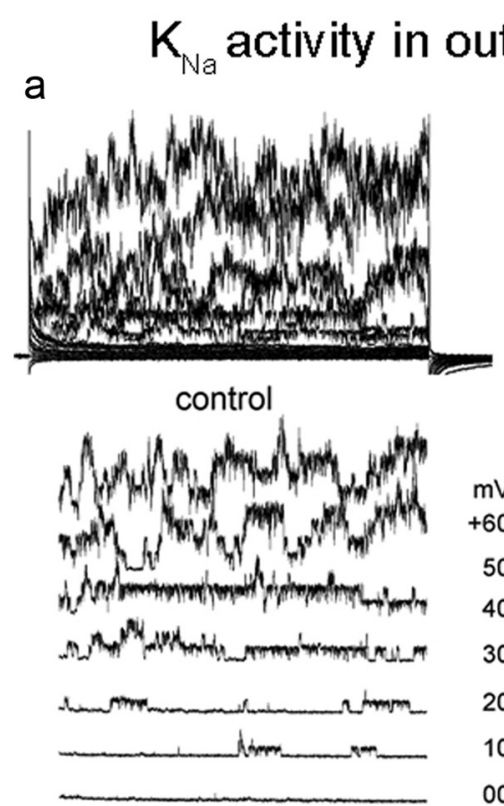

b
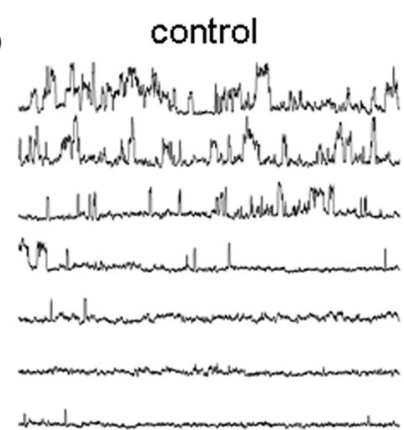

utside-out patch

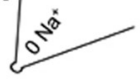

$20 \mathrm{pA}$

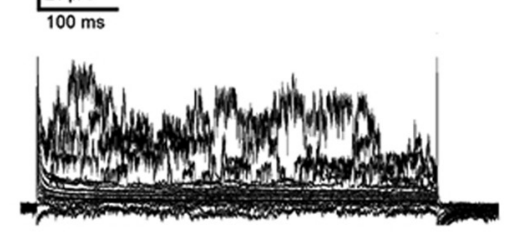

+ TTX
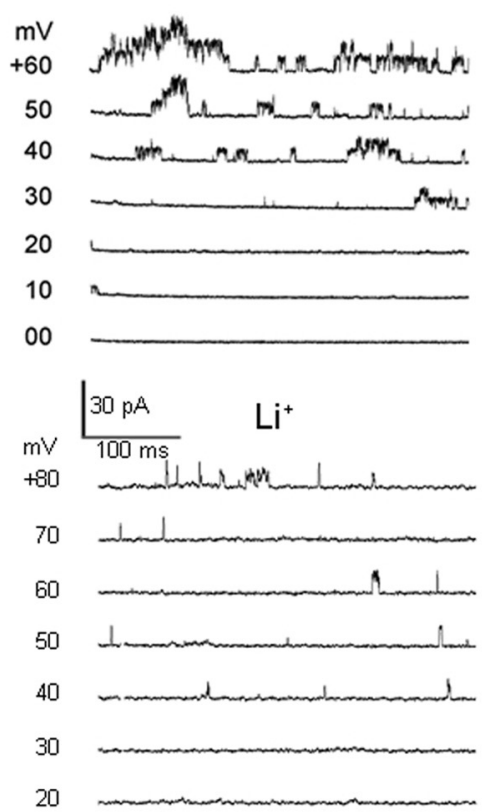

Figure 3. Single-channel $\mathrm{K}_{\mathrm{Na}}$ activity depends on TTX-sensitive persistent sodium influx into an outside-out patch. $\boldsymbol{a}$, Currents evoked by a family of voltage steps in control conditions and in the presence of $\operatorname{TTX}(1 \mu \mathrm{M}) . \mathrm{K}_{\mathrm{Na}}$ channel activation was stimulated by TTX-sensitive entry of sodium ion from the external medium; sodium ion was absent from the internal bulk solution. Upper traces show currents evoked by step pulses from -90 to $+60 \mathrm{mV}$ in $10 \mathrm{mV}$ intervals from a holding potential of $-70 \mathrm{mV}$. Lower traces display distributed traces at indicated voltages to allow resolution of individual $\mathrm{K}_{\mathrm{Na}}$ channel events. $\boldsymbol{b}$, Currents evoked by steps to indicated voltages from a holding potential of $-70 \mathrm{mV}$ in control conditions and after complete replacement of external $\mathrm{Na}^{+}$with $\mathrm{Li}^{+}$.

These results support the hypothesis that both $I_{\mathrm{KNa}}$ and $I_{\mathrm{NaP}}$ currents were present in macropatches.

Only trace amounts of $I_{\mathrm{NaT}}$ were evoked by step pulses from excised patches held at $-70 \mathrm{mV}$ (although patches held at -90 $\mathrm{mV}$ exhibited an obvious $I_{\mathrm{NaT}}$ ). Thus, it is unlikely that $I_{\mathrm{NaT}}$ had any substantial role in evoking the $\mathrm{Na}^{+}$-dependent outward current seen in Figure $2 d$. Since internal $\mathrm{Na}^{+}$was not included in the pipette solution in these experiments, the results imply that persistent $\mathrm{Na}^{+}$influx was responsible. However, because of the low amplitude of $I_{\text {Nap }}$ it is unlikely that there would be a sufficient influx of $\mathrm{Na}^{+}$during the first few milliseconds of a depolarizing step pulse to substantially raise the local $\left[\mathrm{Na}^{+}\right]_{\mathrm{i}}$ near $\mathrm{K}_{\mathrm{Na}}$ channels to a sufficiently high level to permit $I_{\mathrm{KNa}}$ activation. However, as will be shown in a following section, $I_{\text {Nap }}$ was observed at all holding potentials and thus, the most likely mechanism is that a small but persistent influx of $\mathrm{Na}^{+}$at holding or resting potentials maintains $\mathrm{Na}^{+}$at a higher concentration at the site of $\mathrm{K}_{\mathrm{Na}}$ channels than in the bulk cell interior. Since $\mathrm{K}_{\mathrm{Na}}$ channels resemble $\mathrm{Ca}^{2+}$-activated $\mathrm{BK}$ channels in having a voltage-dependent component to their activation, current amplitudes increase with depolarizing step pulses, as seen in Figure 2.
Single-channel $\mathrm{K}_{\mathrm{Na}}$ currents coupled to $\mathrm{Na}^{+}$influx

To examine the functional association of $\mathrm{K}_{\mathrm{Na}}$ channels with $I_{\mathrm{NaP}}$ at higher resolution, we used smaller outside-out patches where we could distinguish the activity of individual $\mathrm{K}_{\mathrm{Na}}$ channels (Fig. 3a). These channels resemble $\mathrm{K}_{\mathrm{Na}}$ channels in insideout patches from T/M cells as previously reported to be abundantly expressed in this cell type (Egan et al., 1992). $\mathrm{K}_{\mathrm{Na}}$ channels from these native cells also resembled sodium-activated SLO2 channels expressed in heterologous systems (Bhattacharjee et al., 2003; Yuan et al., 2003; Santi et al., 2006). The excised patch in Figure $3 a$ contains at least 8 active high conductance channels, and even though single-channel openings are easily discerned, the evoked current as a whole resembles that seen in macropatches as in Figure 2. When TTX $(1 \mu \mathrm{M})$ was perfused on the outside of this patch and others like it, there was a substantial decline in channel activity (Fig. 3a) ( $\mathrm{P}_{\mathrm{o}}$ decreased to $57.3 \pm 3.00 \%$ of control value after application of $1 \mu \mathrm{M}$ TTX, $p<0.001 n=5$, measured at $+60 \mathrm{mV}$ ). These results suggest that, in addition to the high conductance $\mathrm{K}_{\mathrm{Na}}$ channels in the patch which are obvious, the patch also contains TTXsensitive $\mathrm{Na}_{\mathrm{V}}$ channels which are not. We will show in a following section that single-channel $I_{\mathrm{NaP}}$ can be revealed when measures are taken to block $\mathrm{K}^{+}$channels.

Like macroscopic $I_{\mathrm{KNa}}$ seen in wholecell experiments and in macropatches, TTX-sensitive single $\mathrm{K}_{\mathrm{Na}}$ channel activity was observed without the addition of $\mathrm{Na}^{+}$ to our pipette solution (Fig. 3a). Thus, even at the single-channel level it appears that TTX-sensitive sodium influx and not bulk internal $\mathrm{Na}^{+}$was activating $I_{\mathrm{KNa}}$. This seems especially persuasive in these experiments with excised outside-out patches because the volume of solution inside the pipette is enormous relative to the miniscule fluid volume in contact with the inner surface of the membrane patch. In these experiments, bulk $\left[\mathrm{Na}^{+}\right]_{\mathrm{i}}$ is not likely to be significantly altered (see calculations in Materials and Methods). Yet, these experiments clearly show the $\mathrm{Na}^{+}$dependence of single $\mathrm{K}_{\mathrm{Na}}$ channels. Such activity implies that local $\left[\mathrm{Na}^{+}\right]_{\mathrm{i}}$ near $\mathrm{K}_{\mathrm{Na}}$ channels at the intracellular membrane surface was being raised to a higher level than bulk internal $\mathrm{Na}^{+}$by persistent TTX-sensitive $\mathrm{Na}^{+}$influx. As previously reported in whole-cell experiments (Budelli et al., 2009), replacement of external $\mathrm{Na}^{+}$with $\mathrm{Li}^{+}$, decreased observed single $\mathrm{K}_{\mathrm{Na}}$ channel activity in outside-out patches (Fig. $3 b)$. $\left(\mathrm{P}_{\mathrm{o}}\right.$ decreased to $66.0 \pm 4.16 \%$ of control value after replacement of $\mathrm{Na}^{+}$with $\mathrm{Li}^{+}$, $p<0.001$, mean $\pm \operatorname{SEM} n=3$, measured at $+60 \mathrm{mV}$ ).

\section{External veratridine increases local internal $\left[\mathrm{Na}^{+}\right]$}

After demonstrating that removing external $\mathrm{Na}^{+}$or blocking $\mathrm{Na}^{+}$influx decreases $\mathrm{K}_{\mathrm{Na}}$ channel activity in isolated patches, we hypothesized that increasing $\mathrm{Na}^{+}$influx would increase $\mathrm{K}_{\mathrm{Na}}$ 


\section{$\mathrm{K}_{\mathrm{Na}}$ activity in outside-out patch}

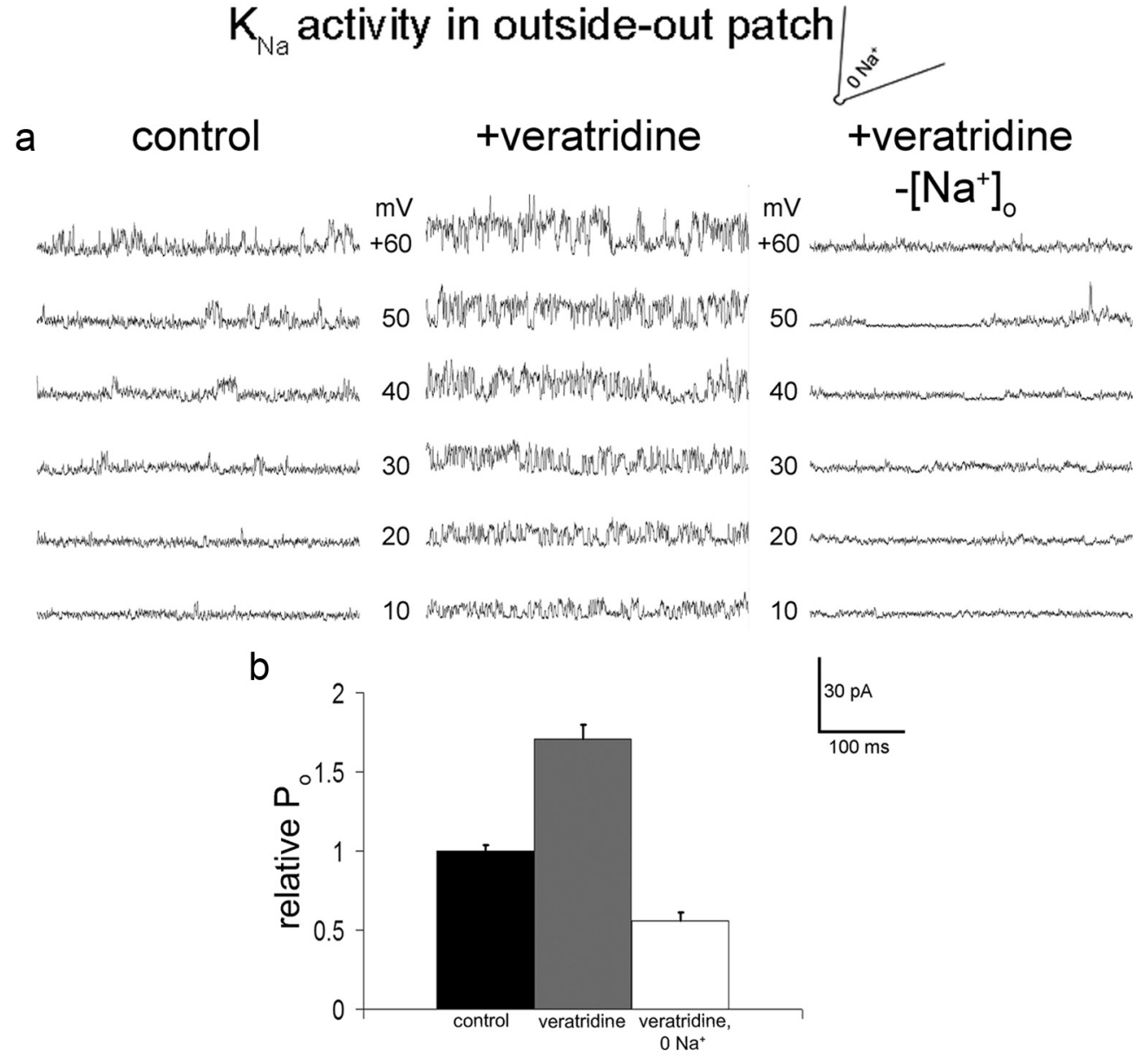

Figure 4. Enhancement of $I_{\mathrm{NaP}}$ increases $\mathrm{K}_{\mathrm{Na}}$ channel activity. $\boldsymbol{a}$, Application of veratridine, which prolongs the open state of the sodium channel, increases $\mathrm{K}_{\mathrm{Na}}$ channel activity. Single-channel $\mathrm{K}_{\mathrm{Na}}$ currents were evoked by steps to indicated voltages from a holding potential of $-70 \mathrm{mV}$ in control conditions (left), after application of veratridine ( $50 \mu \mathrm{m}$; center), and after removal of external $\mathrm{Na}^{+}$in the continued presence of veratridine (right). $\boldsymbol{b}$, The effect of veratridine on $\mathrm{K}_{\mathrm{Na}}$ channel activity in the presence and absence of external $\mathrm{Na}^{+}$was quantified by calculating the $\mathrm{P}_{0}$ of the channels, as described in Materials and Methods, in each condition ( $n=10$ patches). For each experiment, measured $P_{0}$ during individual sweeps was normalized against mean $P_{0}$ in control conditions. Bars represent relative $\mathrm{P}_{0}$ in indicated conditions. Error bars represent SE. $p<0.001$ comparing control to veratridine and veratridine to $0 \mathrm{Na}{ }^{+}$.

channel activity. We applied veratridine $(50 \mu \mathrm{M})$, which prolongs the open state of the sodium channel (Barnes and Hille, 1988), to outside-out patches containing active $\mathrm{K}_{\mathrm{Na}}$ channels, and observed a significant increase in $\mathrm{K}_{\mathrm{Na}}$ channel activity (Fig. 4). The activating effect of veratridine on single $\mathrm{K}_{\mathrm{Na}}$ channel activity could be abolished by the removal of external $\mathrm{Na}^{+}$after application of veratridine. $\left(\mathrm{K}_{\mathrm{Na}}\right.$ channel $\mathrm{P}_{\mathrm{o}}$ increased to $171 \% \pm 9.44 \%$ of control value after application of $50 \mu \mathrm{M}$ veratridine, $p<0.001$, $n=10$, and decreased to $55.7 \pm 12.7 \%$ value following subsequent removal of external $\mathrm{Na}^{+}, p<0.001$, mean $\pm \mathrm{SEM}, n=10$, measured at $+60 \mathrm{mV}$ ). Thus, our interpretation of these results is that veratridine increases $\mathrm{K}_{\mathrm{Na}}$ channel activity by increasing sustained $\mathrm{Na}^{+}$influx via $\mathrm{Na}_{\mathrm{V}}$ channels. We emphasize that the effect of veratridine must be via increasing the local $\left[\mathrm{Na}^{+}\right]$in the vicinity of $\mathrm{K}_{\mathrm{Na}}$ channels and cannot be due to changing the internal bulk $\left[\mathrm{Na}^{+}\right]$. Given the small amplitude of $I_{\mathrm{NaP}}$ in excised patches (see below) and the volume of internal solution used in recording pipettes, increases in bulk $\left[\mathrm{Na}^{+}\right]_{\mathrm{i}}$ are estimated to be well below 1 $\mu \mathrm{M}$ in experiments using outside-out patches (Materials and Methods), which is orders of magnitude below $\left[\mathrm{Na}^{+}\right]$necessary for $\mathrm{K}_{\mathrm{Na}}$ channel activation. Therefore, changes in activity of $\mathrm{K}_{\mathrm{Na}}$ channels upon enhancement of $I_{\mathrm{NaP}}$ by veratridine must be due to local, subcellular changes in $\left[\mathrm{Na}^{+}\right]$.

\section{Persistent $\mathrm{Na}^{+}$currents in patch recordings}

While many of the recordings described above had some indication of macroscopic and single-channel $I_{\mathrm{NaP}}$ currents, accurate recording of $I_{\mathrm{NaP}}$ currents in outside-out patches required blockade of $\mathrm{K}^{+}$channels. This is due to the small single-channel conductance of $\mathrm{Na}_{\mathrm{V}}$-channels, simultaneous activity of $\mathrm{Na}^{+}$and $\mathrm{K}^{+}$ currents and prominent subconductance states of $\mathrm{K}_{\mathrm{Na}}$ channels. We found that both transient and persistent TTX-sensitive sodium currents were present in outside-out patches from the soma (Fig. 5a,b). We observed that $I_{\mathrm{NaP}}$ at a single-channel level consists of brief openings occurring over a wider voltage range than $I_{\mathrm{NaT}}$ and displaying no significant inactivation over the course of $1 \mathrm{~s}$ voltage steps. Many of these persistent TTX-sensitive openings were so brief that we could not reliably measure a mean channel open time, even when digitizing at high rates. Thus, we used the number of detectable events as a means of quantification rather than channel open probability (Fig. 5b). Because of the brevity of openings it is likely that we failed to detect many of them. Although TTX-sensitive openings of $I_{\mathrm{NaP}}$ occurred less frequently at hyperpolarized voltages, they were clearly present even at -90 $\mathrm{mV}$ (Fig. $5 b$ ). $I_{\mathrm{NaP}}$ with similar voltage-sensitivity was identified in whole-cell recordings using voltage steps and slow voltage ramps (Fig. $5 c, d$ ). These results suggest $I_{\mathrm{NaP}}$ is a determinant of 

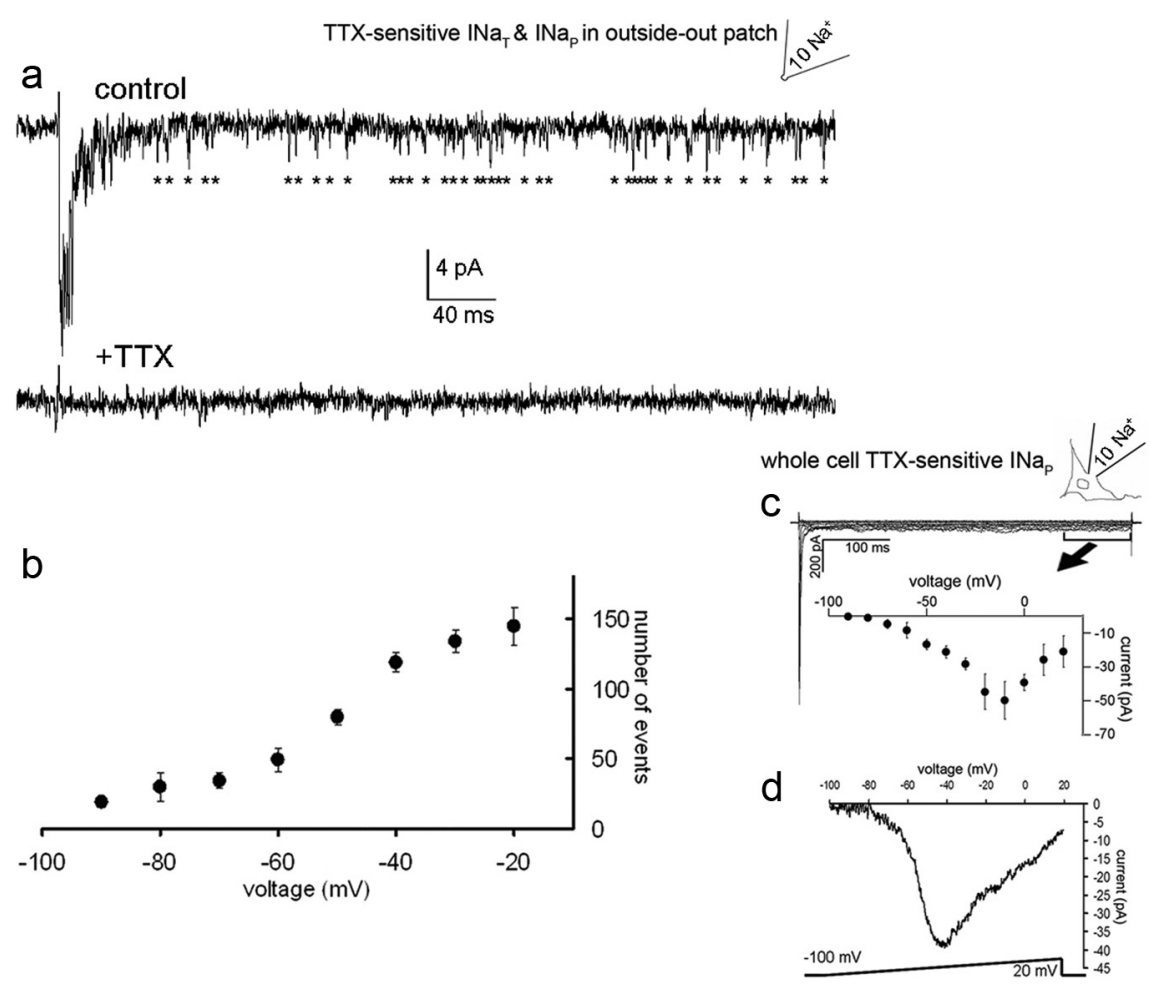

Figure 5. Voltage-gated sodium currents present in the soma of T/M cells include a persistent component. Sodium currents were isolated by using $C s^{+}$in the patch pipette and TEA and 4-AP in the bath to block potassium channels. $a-d$, Recordings were made in outside-out patches $(\boldsymbol{a}, \boldsymbol{b})$ and whole-cell configuration $(\boldsymbol{c}, \boldsymbol{d})$ with the internal sodium concentration set to $10 \mathrm{~mm}$ to obtain better voltage control of inward current and allow measurement of channel reversal potential. $\boldsymbol{a}$, Single-channel sodium currents evoked by a voltage step from -90 to $-40 \mathrm{mV}$ have both early occurring, high open probability, transient openings, as well as low probability, persistently recurring, brief openings (asterisks). Both components were blocked by TTX (1 $\mu \mathrm{m}) . \boldsymbol{b}$, Plot of the number of channel opening events versus voltage. Channel events were counted from $50 \mathrm{~ms}$ after the initiation of a $1 \mathrm{~s}$ voltage step to its end. c, Whole-cell, TTX-sensitive persistent sodium currents evoked by $500 \mathrm{~ms}$ steps to indicated voltages from a holding potential of $-90 \mathrm{mV}$. Mean current is plotted during the last $100 \mathrm{~ms}$ of the pulse (arrow). Error bars represent SEM. $n=5$ cells. $\boldsymbol{d}$, Whole-cell, TTX-sensitive sodium currents evoked by a voltage ramp from -100 to $+20 \mathrm{mV}, 40 \mathrm{mV} / \mathrm{s}$. In c and $\boldsymbol{d}$, TTX-sensitive currents were isolated and plotted by subtracting residual currents evoked in TTX (1 $\mu \mathrm{M})$ from currents evoked before TTX application.

the resting potential in $\mathrm{T} / \mathrm{M}$ cells. Consistent with this, the resting potential of mitral cells undergoes subthreshold oscillations in membrane voltage known to be mediated by TTX-sensitive $I_{\mathrm{Na}}$ (Desmaisons et al., 1999). This finding was consistent with our earlier whole-cell experiments that seemed to indicate that at cell resting potentials $\mathrm{K}_{\mathrm{Na}}$ channels were maintained in a "primed" state under normal physiological conditions, which, given the small voltage-sensitive component to $\mathrm{K}_{\mathrm{Na}}$ channel gating, produces a delayed outward current upon sufficient membrane depolarization. Such a "primed" state is likely to be the result of a tiny but persistent replenishment of $\mathrm{Na}^{+}$in the local vicinity of $\mathrm{K}_{\mathrm{Na}}$ which maintains local $\left[\mathrm{Na}^{+}\right]_{\mathrm{i}}$ at a higher level than bulk $\left[\mathrm{Na}^{+}\right]_{\mathrm{i}} \cdot I_{\mathrm{NaT}}$ in excised patches displayed an unusually hyperpolarized steady-state inactivation curve $\left(\mathrm{V}_{1 / 2}=-81.7 \pm 1.3 \mathrm{mV}\right.$, peak current measured at $-20 \mathrm{mV}$ following $1 \mathrm{~s}$ prepulses of -120 to $-30 \mathrm{mV}, n=6$ patches). Consistent with the lack of apparent $I_{\mathrm{NaT}}$ in our recordings of $\mathrm{K}_{\mathrm{Na}}$ channel activity, only $\sim 10 \%$ of the sodium channels contribute to $I_{\mathrm{NaT}}$ evoked from a holding potential of $-70 \mathrm{mV}$. Atypically hyperpolarized sodium channel inactivation (of the transient component) has recently been reported in other mammalian neurons as well (Grimes et al., 2010; Scott et al., 2010). To confirm that $I_{\mathrm{Na}}$ in excised patches was sensitive to veratridine, we applied veratridine to an outside-out patch in which $I_{\mathrm{Na}}$ was isolated. Upon application of $50 \mu \mathrm{M}$ veratridine, we observed substantially increased $I_{\mathrm{NaP}}$ activity during voltage steps and a prominent, slowly decaying tail current upon repolarization (Fig. $6 a, b)$ consistent with previous reports of its action on $I_{\mathrm{Na}}$ (Barnes and Hille, 1988).

\section{Discussion}

Upon initial identification in cardiac myocytes, the suggested role for $K_{\mathrm{Na}}$ channels was that of providing a reserve conductance that would protect cells during hypoxia when an elevation in $\left[\mathrm{Na}^{+}\right]_{\mathrm{i}}$ occurred as a result of blocking the $\mathrm{Na}^{+} / \mathrm{K}^{+}$ATPase (Kameyama et al., 1984). This idea arose as a result of observations of $\mathrm{K}_{\mathrm{Na}}$ channels in inside-out patches which showed that $\mathrm{K}_{\mathrm{Na}}$ channel activation required a much higher $\left[\mathrm{Na}^{+}\right]_{\mathrm{i}}$ than that normally found in bulk cytoplasm. However, we have uncovered an unexpected phenomenon by which $\mathrm{Na}^{+}$ entering the cell via a small but persistent sodium current is surprisingly effective in activating $I_{\mathrm{KNa}}$, even in the total absence of bulk internal $\mathrm{Na}^{+}$. The seeming implausibility of such a mechanism may be partially responsible for keeping this major and widespread component of delayed outward conductance unappreciated by electrophysiologists for many years. These observations suggest a mechanism by which $I_{\mathrm{KNa}}$ can commonly participate in providing a large outward conductance in many neuronal types. $\mathrm{K}_{\mathrm{Na}}$ channels are expressed throughout the brain (Bhattacharjee et al., 2002, 2005). The Allen Brain Atlas shows that one of two genes which encode $\mathrm{K}_{\mathrm{Na}}$ channels (KCNT1, also known as Slack and Slo2.2) is as widespread and abundantly expressed as KCNB1, the gene encoding the major voltage-dependent delayed rectifier (http://mouse.brain-map.org/).

The functional coupling of $I_{\mathrm{KNa}}$ to $I_{\mathrm{NaP}}$ that we observe at the single-channel level in isolated outside-out patches suggests a highly specialized relationship between $\mathrm{K}_{\mathrm{Na}}$ and $\mathrm{Na}_{\mathrm{V}}$ channels perhaps similar to the colocalization between calcium channels and the Slol calcium-activated potassium channel (BK) (Marrion and Tavalin, 1998). Although the coupling of $\mathrm{K}_{\mathrm{Na}}$ to $\mathrm{Na}$ channels may be analogous, the two orders of magnitude difference in the required concentrations of $\mathrm{Na}^{+}$and $\mathrm{Ca}^{2+}$ needed to activate the respective $\mathrm{K}^{+}$-channels suggests some differences. Hence, we are unlikely to observe a correlation between the opening of single $\mathrm{Na}_{\mathrm{V}}$ and $\mathrm{K}_{\mathrm{Na}}$ channels as is observed between calcium channels and single BK channels. Nevertheless there are may parallels between the two systems. In both systems the channels are activated by two major factors, an intracellular ion ligand, and voltage (albeit $\mathrm{K}_{\mathrm{Na}}$ channels have lower voltage sensitivity). In both systems, the effect of increasing the concentration of the intracellular ion ligand is to shift the conductancevoltage relation leftward to more hyperpolarized voltages. We previously demonstrated this for $I_{\mathrm{KNa}}$ by loading cells with higher concentrations of $\mathrm{Na}^{+}$and noting a leftward shift in the conductance-voltage relation of $I_{\mathrm{KNa}}$ (Budelli et al., 2009).Signif- 
icantly, those experiments showed that cells loaded with higher concentrations of $\left[\mathrm{Na}^{+}\right]_{\mathrm{i}}$ still retained an obvious delayed outward component of $I_{\mathrm{KNa}}$ due to the influx of $\mathrm{Na}^{+}$. Thus, the TTX-dependent influx of $\mathrm{Na}^{+}$appears to be additive to the $\left[\mathrm{Na}^{+}\right]_{\mathrm{i}}$ contributed by the bulk solution.

A possible mechanism for the functional coupling of $\mathrm{K}_{\mathrm{Na}}$ and $I_{\mathrm{NaP}}$ is their presence in a region of limited diffusion near the plasma membrane, sometimes described as a fuzzy space or unstirred layer. Physiological evidence of such a region in cardiac myocytes has been accumulating for many years (for review, see Barry, 2006). Microheterogeneity of sodium concentrations in internal submembrane space has been inferred many times (Barry, 2006), and has even been directly measured (Wendt-Gallitelli et al., 1993). Measurements using electromagnetic pulse analysis shows $\left[\mathrm{Na}^{+}\right]$near the inner membrane surface can be severalfold higher than the bulk $\left[\mathrm{Na}^{+}\right]_{\mathrm{i}}$ and heterogeneous within a cell, ranging from 0 to 80 $\mathrm{mM}$ at the inner membrane surface. Thus, it is possible that a small but constant influx of $\mathrm{Na}^{+}$through $I_{\mathrm{NaP}}$ is responsible for increasing $\left[\mathrm{Na}^{+}\right]$in some submembrane regions where $\mathrm{K}_{\mathrm{Na}}$ channels are located, and that limited diffusion as well as colocalization of $I_{\mathrm{NaP}}$ and $I_{\mathrm{KNa}}$ both contribute to activation of $I_{\mathrm{KNa}}$ by $I_{\mathrm{NaP}}$.

This study focused on $I_{\mathrm{NaP}}$ as a major source of sodium for the activation of $\mathrm{K}_{\mathrm{Na}}$ channels. While our data suggest $I_{\mathrm{NaT}}$ is not necessary for $\mathrm{K}_{\mathrm{Na}}$ activation as a delayed outward current, we have not ruled out a contribution of $I_{\mathrm{NaT}}$ in all circumstances. The $\mathrm{Na}_{\mathrm{V}}$-channels that carry $I_{\mathrm{NaP}}$ are likely to also carry $I_{\mathrm{NaT}}$, and it is difficult to imagine a mechanism by which only persistent $\mathrm{Na}^{+}$-channel activity would activate $\mathrm{K}_{\mathrm{Na}}$ channels. However, our study indicates that the $\mathrm{Na}^{+}$-channels present in somal membrane may be largely inactivated at resting membrane potentials with regard to their capacity to carry a transient sodium current on depolarization, while maintaining the ability to carry $I_{\mathrm{NaP}}$ at most voltages. Activation of $I_{\mathrm{KNa}}$ by $I_{\mathrm{NaT}}$ has been previously examined in outside-out patches of neurons from chick brainstem (Dryer, 1991). That study found that while TTX blocked $I_{\mathrm{NaT}}$ it had no effect on potassium currents. However, those experiments observed the effects of $I_{\mathrm{NaT}}$ on outward currents at -25 to $-10 \mathrm{mV}$, near peak $I_{\mathrm{NaT}}$ amplitude. We point out that, under conditions of low $[\mathrm{Na}]_{\mathrm{i}}$ loading, we also do not detect net outward $I_{\mathrm{KNa}}$ at those voltages, which we ascribe to the voltagedependent component of $I_{\mathrm{KNa}}$ activation. Thus, Dryer's experiments must be repeated at higher voltages before ruling out a role for $I_{\mathrm{NaT}}$ in $\mathrm{K}_{\mathrm{Na}}$ activation.

The activity of $\mathrm{K}_{\mathrm{Na}}$ channels has been shown to be sensitive to intracellular $\mathrm{Cl}^{-}$(Bhattacharjee et al., 2003; Yuan et al., 2003). We have found the magnitude of TTX-sensitive outward current in whole-cell recordings to be accordingly affected by $\left[\mathrm{Cl}^{-}\right]_{\mathrm{i}}$. TTX-sensitive potassium currents in recordings using a physiological $\left[\mathrm{Cl}^{-}\right]_{\mathrm{i}}$ of $20 \mathrm{~mm}$ comprise $\sim 30 \%$ of the sustained outward

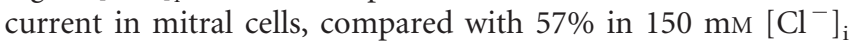
(Budelli et al., 2009; our unpublished data). Our current study used an elevated $\left[\mathrm{Cl}^{-}\right]_{\mathrm{i}}$ to increase the likelihood of observing
$\mathrm{K}_{\mathrm{Na}}$ channels and to more precisely measure channel $\mathrm{P}_{\mathrm{o}} . \mathrm{K}_{\mathrm{Na}}$ channels have been shown to be activated by the ubiquitous enzyme cofactor nicotinamide adenine dinucleotide $\left(\mathrm{NAD}^{+}\right)$ (Tamsett et al., 2009). The presence of $\mathrm{NAD}^{+}$may increase the activity of $\mathrm{K}_{\mathrm{Na}}$ channels at physiological concentrations of internal bulk $\mathrm{Na}^{+}$.

The contribution of $I_{\mathrm{NaP}}$ to the activation of a prominent potassium conductance may seem counterintuitive given the established role of $I_{\mathrm{NaP}}$ in increasing neuronal excitability. We point out that the $I_{\mathrm{NaP}}-I_{\mathrm{KNa}}$ coupled system produces a net inward current in mitral cells between typical resting potentials and action potential thresholds (Figs. $1 c, d, 2 e$ ). Nevertheless, within those voltages the activation of $I_{\mathrm{KNa}}$ may mitigate depolarization and while it does not overcome $I_{\mathrm{NaP}}$, could provide some negative feedback against the excitatory role of $I_{\mathrm{NaP}}$, in the form of membrane accommodation. It may also act as a repolarizing current that shortens action potential duration. In addition, there is evidence for neuromodulatory regulation of both $I_{\mathrm{NaP}}$ (for review, see Cantrell and Catteral, 2001) and $I_{\mathrm{KNa}}$ (Santi et al., 2006; Nuwer et al., 2010). Hence, the discrete or combined regulation of either component of the $I_{\mathrm{NaP}}-I_{\mathrm{KNa}}$ coupled system could provide a mechanism for long-lasting changes in excitable properties over a wide range of both subthreshold and depolarized voltages.

$I_{\mathrm{NaT}}$ and the upstroke of action potentials are grossly similar across neurons. In contrast, the behavior of $I_{\mathrm{NaP}}$ varies and contributes to diverse physiological properties such as amplification of synaptic potentials, repetitive firing of action potentials, spike timing, and even membrane resting potential (Crill, 1996; Vervaeke et al., 2006, Huang and Trussell, 2008). Indeed, $I_{\mathrm{NaP}}$ may be a significant determinant of some of the most subtle excitable membrane behavior such as electrical resonance generating theta frequency firing (Hu et al., 2002). In all of these electrical phenomena in which $I_{\mathrm{NaP}}$ participates, $I_{\mathrm{KNa}}$ may now be found to be 
a coparticipant. Many inherited epilepsies are due to gain- or loss-of-function mutations in voltage-gated sodium channels which alter $I_{\mathrm{NaP}}$. Accordingly, several antiepileptic drugs primarily target $I_{\mathrm{NaP}}$; however, understanding of pathophysiological mechanisms of $I_{\mathrm{NaP}}$ toward epilepsy and other disorders is incomplete (Stafstrom, 2007; Saint, 2008; Waxman, 2008). For all these reasons, $I_{\mathrm{NaP}}$ is a topic of great research interest for clinical and basic neuroscientists. The functional coupling of $I_{\mathrm{NaP}}$ to $\mathrm{K}_{\mathrm{Na}}$ channels must now also be considered as the contribution of $I_{\mathrm{NaP}}$ to neuronal physiology continues to be investigated.

\section{References}

Barnes S, Hille B (1988) Veratridine modifies open sodium channels. J Gen Physiol 91:421-443.

Barry WH (2006) Na "Fuzzy space": does it exist, and is it important in ischemic injury? J Cardiovasc Electrophysiol S1:S43-S46.

Bhattacharjee A, Kaczmarek LK (2005) For $\mathrm{K}^{+}$channels, $\mathrm{Na}^{+}$is the new $\mathrm{Ca}^{2+}$. Trends Neurosci 28:422-428.

Bhattacharjee A, Gan L, Kaczmarek LK (2002) Localization of the Slack potassium channel in the rat central nervous system. J Comp Neurol 454:241-254.

Bhattacharjee A, Joiner WJ, Wu M, Yang Y, Sigworth FJ, Kaczmarek LK (2003) Slick (Slo2.1), a rapidly-gating sodium-activated potassium channel inhibited by ATP. J Neurosci 23:11681-11691.

Bhattacharjee A, von Hehn CA, Mei X, Kaczmarek LK (2005) Localization of the $\mathrm{Na}^{+}$-activated $\mathrm{K}^{+}$channel Slick in the rat central nervous system. J Comp Neurol 484:80-92.

Budelli G, Hage TA, Wei A, Rojas P, Jong YJ, O’Malley K, Salkoff L (2009) $\mathrm{Na}^{+}$-activated $\mathrm{K}^{+}$channels express a large delayed outward current in neurons during normal physiology. Nat Neurosci 12:745-750.

Cantrell AR, Catterall WA (2001) Neuromodulation of $\mathrm{Na}^{+}$channels: an unexpected form of cellular plasticity. Nat Rev Neurosci 2:397-407.

Crill WE (1996) Persistent sodium current in mammalian central neurons. Annu Rev Physiol 58:349-362.

Desmaisons D, Vincent JD, Lledo PM (1999) Control of action potential timing by intrinsic subthreshold oscillations in olfactory bulb output neurons. J Neurosci 19:10727-10737.

Dryer SE (1991) $\mathrm{Na}(+)$-activated $\mathrm{K}^{+}$channels and voltage-evoked ionic currents in brain stem and parasympathetic neurones of the chick. J Physiol 435:513-532.

Dryer SE (1994) $\mathrm{Na}(+)$-activated $\mathrm{K}^{+}$channels: a new family of largeconductance ion channels. Trends Neurosci 17:155-160.

Egan TM, Dagan D, Kupper J, Levitan IB (1992) Properties and rundown of sodium-activated potassium channels in rat olfactory bulb neurons. J Neurosci 12:1964-1976.

Grimes WN, Zhang J, Graydon CW, Kachar B, Diamond JS (2010) Retinal parallel processors: more than 100 independent microcircuits operate within a single interneuron. Neuron 65:873-885.

Hu H, Vervaeke K, Storm JF (2002) Two forms of electrical resonance at theta frequencies, generated by $\mathrm{M}$-current, $\mathrm{h}$-current and persistent $\mathrm{Na}+$ current in rat hippocampal pyramidal cells. J Physiol 545:783-805.

Huang H, Trussell LO (2008) Control of presynaptic function by a persistent $\mathrm{Na}(+)$ current. Neuron 60:975-979.

Kameyama M, Kakei M, Sato R, Shibasaki T, Matsuda H, Irisawa H (1984) Intracellular $\mathrm{Na}^{+}$activates a $\mathrm{K}^{+}$channel in mammalian cardiac cells. Nature 309:354-356.

Lu S, Das P, Fadool DA, Kaczmarek LK (2010) The slack sodium-activated potassium channel provides a major outward current in olfactory neurons of Kv13-/- super-smeller mice. J Neurophysiol 103:3311-3319.

Marrion NV, Tavalin SJ (1998) Selective activation of $\mathrm{Ca}^{2+}$-activated $\mathrm{K}^{+}$ channels by co-localized $\mathrm{Ca}^{2+}$ channels in hippocampal neurons. Nature 395:900-905.

Nuwer MO, Picchione KE, Bhattacharjee A (2010) PKA-induced internalization of slack $\mathrm{KNa}$ channels produces dorsal root ganglion neuron hyperexcitability. J Neurosci 30:14165-14172.

Saint DA (2008) The cardiac persistent sodium current: an appealing therapeutic target? Br J Pharmacol 153:1133-1142.

Santi CM, Ferreira G, Yang B, Gazula VR, Butler A, Wei A, Kaczmarek LK, Salkoff L (2006) Opposite regulation of Slick and Slack $\mathrm{K}^{+}$channels by neuromodulators. J Neurosci 26:5059-5068.

Scott LL, Mathews PJ, Golding NL (2010) Perisomatic voltage-gated sodium channels actively maintain linear synaptic integration in principal neurons of the medial superior olive. J Neurosci 30:2039-2050.

Stafstrom CE (2007) Persistent sodium current and its role in epilepsy. Epilepsy Curr 7:15-22.

Stafstrom CE, Schwindt PC, Crill WE (1984) Repetitive firing in layer V neurons from cat neocortex in vitro. J Neurophysiol 52:264-277.

Tamsett TJ, Picchione KE, Bhattacharjee A (2009) NAD $^{+}$activates $\mathrm{KNa}$ channels in dorsal root ganglion neurons. J Neurosci 29:5127-5134.

Trombley PQ, Westbrook GL (1990) Excitatory synaptic transmission in cultures of rat olfactory bulb. J Neurophysiol 64:598-606.

Vervaeke K, Hu H, Graham LJ, Storm JF (2006) Contrasting effects of the persistent $\mathrm{Na}^{+}$current on neuronal excitability and spike timing. Neuron 49:257-270.

Waxman SG (2008) Mechanisms of disease: sodium channels and neuroprotection in multiple sclerosis-current status. Nat Clin Pract Neurol 4:159-169.

Wendt-Gallitelli MF, Voigt T, Isenberg G (1993) Microheterogeneity of subsarcolemmal sodium gradients. Electron probe microanalysis in guinea-pig ventricular myocytes. J Physiol 472:33-44.

Yuan A, Santi CM, Wei A, Wang ZW, Pollak K, Nonet M, Kaczmarek L, Crowder CM, Salkoff L (2003) The sodium-activated potassium channel is encoded by a member of the Slo gene family. Neuron 37:765-773. 